Endüstri llişkileri ve Insan Kaynakları Dergisi

Cilt:17 -Sayı:3 -Temmuz 2015

\begin{tabular}{|c|c|c|}
\hline & MAKALE ADI & SAYFA \\
\hline 1 & 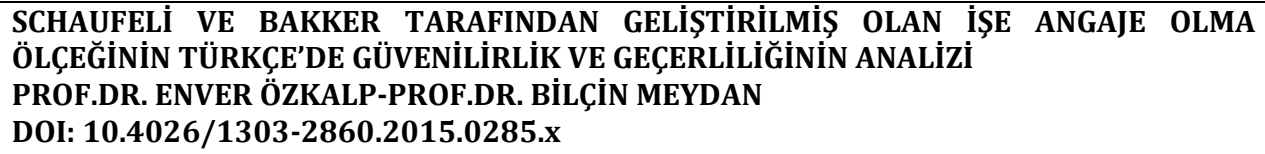 & 4-19 \\
\hline 2 & $\begin{array}{l}\text { ARAŞTIRMALARDA İSTATİSTİK VE ETİK } \\
\text { PROF. DR. NURAN BAYRAM } \\
\text { DOI: } 10.4026 / 1303-2860.2015 .0286 . x\end{array}$ & $20-29$ \\
\hline 3 & $\begin{array}{l}\text { LABOUR LAW AWARENESS OF EMPLOYEES: A COMPARISON FROM GERMANY AND } \\
\text { TURKEY } \\
\text { PROF. DR. ÖMER SADULLAH-ASSOC.PROF.DR. FULYA AYDINLI KULAK-MELTEM } \\
\text { SERMET } \\
\text { DOI: 10.4026/1303-2860.2015.0287.x }\end{array}$ & $30-48$ \\
\hline 4 & $\begin{array}{l}\text { SKILLED WORKFORCE TRAINING PROGRAMS FOR THE TURKISH TEXTILE AND } \\
\text { APPAREL INDUSTRY, CASE OF DENIZLI } \\
\text { ASSOC.PROF.DR.SEMA PALAMUTCU, NEDIM DOĞAN } \\
\text { DOI: 10.4026/1303-2860.2015.0288.X }\end{array}$ & $49-60$ \\
\hline 5 & $\begin{array}{l}\text { DEĞIŞEN İŞ ORTAMINDA BİREYE AİT DİNAMIKLER: ÖZ-DENETIM'İN ROLÜ YARD. DOÇ. } \\
\text { DR. ESRA ATILLA BAL } \\
\text { DOI: 10.4026/1303-2860.2015.0289.X }\end{array}$ & $61-71$ \\
\hline 6 & $\begin{array}{l}\text { ULUSLARARASI TİCARETIN ADALETINII SORGULAMAK: ADİL TİCARET SISTEMİ, } \\
\text { ÇALIŞMA KOŞULLARINA ETKİİ VE FINDIK IŞ̧ÇILERİ İÇIN “ADALET” ARAYIŞI } \\
\text { YARD.DOÇ.DR.ASLI ŞEN TAŞBAŞI } \\
\text { DOI: 10.4026/1303-2860.2015.0290.X }\end{array}$ & $72-92$ \\
\hline 7 & $\begin{array}{l}\text { KIŞiLíĞE YÖNELİK YILDIRMA (MOBBING) DAVRANIŞLARI ve FİZYOLOJİK ETKİLER } \\
\text { ARASINDAKİ İLIŞKİE PSIKOLOJİK ETKILLERIN ARACILIK ROLÜ } \\
\text { YARD. DOÇ. DR. HAKAN SEZEREL, YARD. DOÇ. DR. SEDAT BOSTAN, YARD. DOÇ. DR. } \\
\text { TARHAN OKAN } \\
\text { DOI: 10.4026/1303-2860.2015.0291.X }\end{array}$ & 93-118 \\
\hline 8 & $\begin{array}{l}\text { ETİKSEL DAVRANIŞLAR VE ETİKSEL İKLİMİN MOBBİNG ÜZERİNDEKİ ETKİSİ: BİR ALAN } \\
\text { ARAŞTIRMASI -DR. FİKRET SÖZBİLIR } \\
\text { DOI: } 10.4026 / 1303-2860.2015 .0292 . x\end{array}$ & $119-140$ \\
\hline 9 & $\begin{array}{l}\text { MAVİ YAKALI ÇALIŞANLAR: NEDEN AKADEMİK ÇALIŞMALAR İÇİN CAZİP BİR } \\
\text { ÖRNEKLEM DEĞIL? } \\
\text { PROF. DR. SERKAN BAYRAKTAROĞLU, DOÇ. DR. YASEMİN ÖZDEMİR, ARŞ. GÖR. } \\
\text { MUSTAFA ARAS, ARŞ. GÖR. SAMET ÖZDEMİR } \\
\text { DOI: 10.4026/1303-2860.2015.0293.X }\end{array}$ & 141-157 \\
\hline 10 & $\begin{array}{l}\text { KARMA ÇALIŞMA ÖLÇEĞİIIN TÜRKÇE FORMUNUN GEÇERLİK VE GÜVENİRLİĞİ } \\
\text { DOÇ.DR.AHMET AKIN , ARŞ.GÖR.MEHMET BAŞÖREN } \\
\text { DOI: 10.4026/1303-2860.2015.0294.X }\end{array}$ & $161-167$ \\
\hline 11 & $\begin{array}{l}\text { GENDER DIFFERENCES IN WORK EXPERIENCES AND WORK AND LEARNING OUTCOMES } \\
\text { AMONG EMPLOYEES IN THE MANUFACTURING SECTOR IN TURKEY: AN EXPLORATORY } \\
\text { STUDY } \\
\text { PROF.DR.RONALD BURKE, PROF.DR.MUSTAFA KOYUNCU, JACOB WOLPIN, } \\
\text { ASST.PROF.DR.FÜSUN TEKIN ACAR, KADIFE KOYUNCU } \\
\text { DOI: } 10.4026 / 1303-2860.2015 .0295 . x\end{array}$ & $168-183$ \\
\hline
\end{tabular}




\section{KÜNYE}

İş,Güç, Endüstri İlişkileri ve İnsan Kaynaklar Dergisi, yılda dört kez yayınlanan hakemli, bilimsel elektronik dergidir. Çalışma hayatna ilişkin makalelere yer verilen derginin temel amact, belirlenen alanda akademik gelişime ve paylaşıma katkıda bulunmaktadır. İş, Güç, Endüstri İlişkileri ve İnsan Kaynakları Dergisi, 'Türkçe' ve 'Ingilizce’ olarak iki dilde makale yaymlanmaktadir.

Is,Guc The Jorunal of Industrial Relations and Human Resources is peer-reviewed, quarterly and electronic open sources journal. IsGuc covers all aspects of working life and aims sharing new developments in industrial relations and human resources also adding values on related disciplines. Is, Guc The Jorunal of Industrial Relations and Human Resources is published Turkish or English language.

\section{Editörler Kurulu / Editorial Board}

Aşkan Keser (Uludağ University)

K.Ahmet Sevimli (Uludağ University)

Şenol Baştürk (Uludağ University)

\section{Editör / Editor in Chief}

Şenol Baştürk (Uludağ University)

\section{Yaym Kurulu / Editorial Board}

Doç.Dr.Erdem Cam (ÇASGEM)

Yrd.Doç.Dr.Zerrin Furat (Uludağ University)

Prof.Dr.Aşkın Keser (Uludağ University)

Prof.Dr.Ahmet Selamoğlu (Kocaeli University)

Yrd.Doç.Dr.Ahmet Sevimli (Uludağ University)

Prof.Dr.Abdulkadir Şenkal (Kocaeli University)

Doç.Dr.Gözde Yllmaz (Marmara University)

Yrd.Doç.Dr.Dr.Memet Zencirkuran (Uludağ University)

\section{Uluslararası Danışma Kurulu / International Advisory Board}

Prof.Dr.Ronald Burke (York University-Kanada)

Assoc.Prof.Dr.Glenn Dawes (James Cook University-Avustralya)

Prof.Dr.Jan Dul (Erasmus University-Hollanda)

Prof.Dr.Alev Efendioğlu (University of San Francisco-ABD)

Prof.Dr.Adrian Furnham (University College London-İngiltere)

Prof.Dr.Alan Geare (University of Otago- Yeni Zellanda)

Prof.Dr. Ricky Griffin (TAMU-Texas A\&M University-ABD)

Assoc. Prof. Dr. Diana Lipinskiene (Kaunos University-Litvanya)

Prof.Dr.George Manning (Northern Kentucky University-ABD)

Prof. Dr. William (L.) Murray (University of San Francisco-ABD)

Prof.Dr.Mustafa Özbilgin (Bruner University-UK)

Assoc. Prof. Owen Stanley (James Cook University-Avustralya)

Prof.Dr.Işık Urla Zeytinoğlu (McMaster University-Kanada) 


\section{Ulusal Danışma Kurulu / National Advisory Board}

Prof.Dr.Yusuf Alper (Uludağ University)

Prof.Dr.Serpil Aytaç (Uludağ University)

Prof.Dr.Veysel Bozkurt (İstanbul University)

Prof.Dr.Toker Dereli (Işık University)

Prof.Dr.Nihat Erdoğmuş (İstanbul Şehir University)

Prof.Dr.Ahmet Makal (Ankara University)

Prof.Dr.Ahmet Selamoğlu (Kocaeli University)

Prof.Dr.Nadir Suğur (Anadolu University)

Prof.Dr.Nursel Telman (Maltepe University)

Prof.Dr.Cavide Uyargil (İstanbul University)

Prof.Dr.Engin Ylldirm (Anayasa Mahkemesi)

Doç.Dr.Arzu Wasti (Sabancı University)

\section{Tarandığı Indeksler/Indexes}
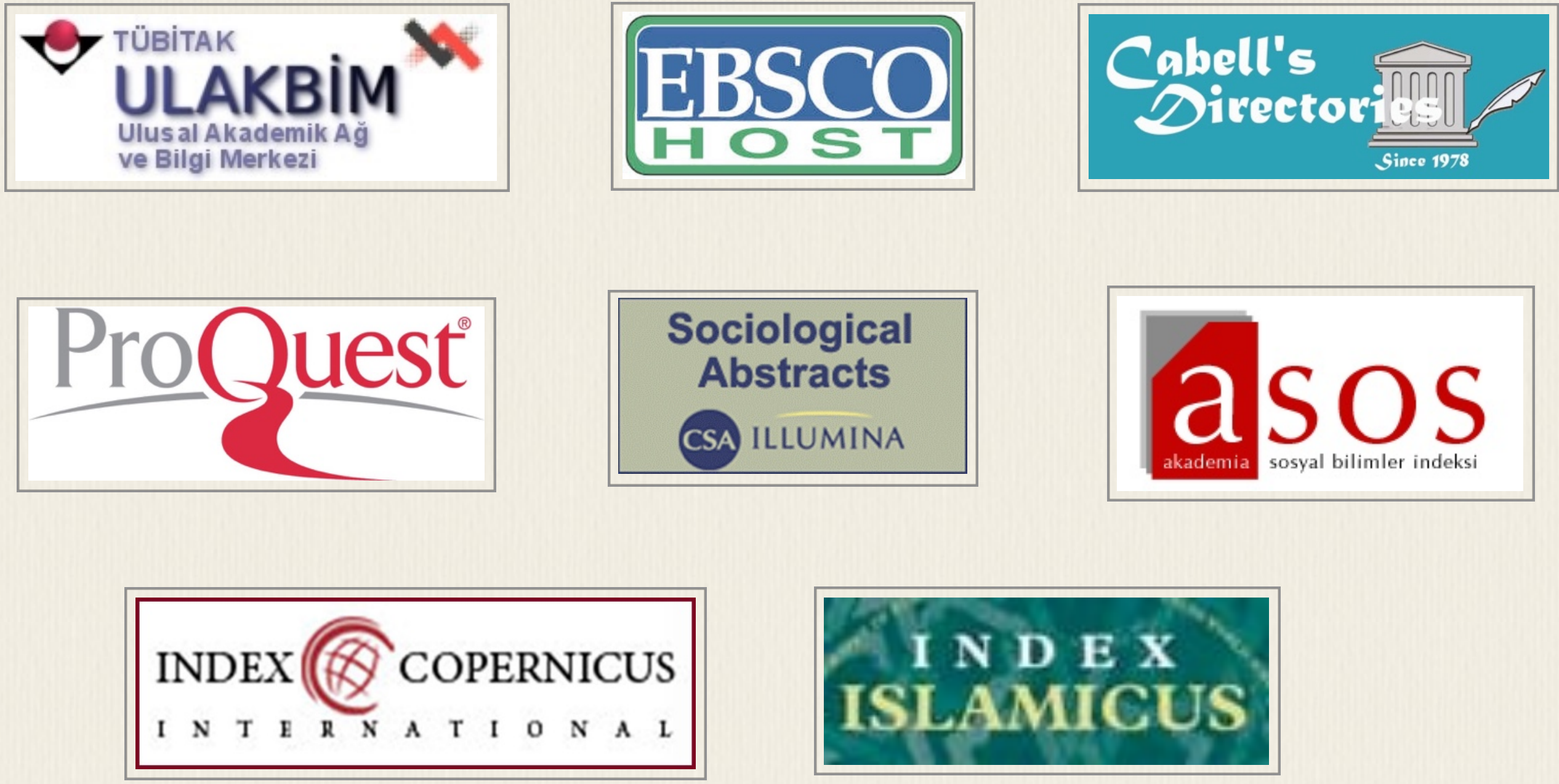

Dergide yayınlanan yazılardaki görüşler ve bu konudaki sorumluluk yazarlarnna aittir. Yayınlanan eserlerde yer alan tüm içerik kaynak gösterilmeden kullanılamaz.

All the opinions written in articles are under responsibilities of the outhors.

The published contents in the articles cannot be used without being cited

“İşGüç” Endüstri İlişkileri ve İnsan Kaynakları Dergisi - (C) 20oo- 2015

"Is,Guc" The Journal of Industrial Relations and Human Resources - (C) 200o- 2015 


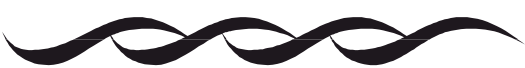

\title{
LABOUR LAW AWARENESS OF EMPLOYEES: A COMPARISON FROM GERMANY AND TURKEY
}

\author{
PROF. DR. ÖMER SADULLAH \\ ASSOC.PROF.DR. FULYA AYDINLI KULAK ${ }^{*}$ \\ MELTEM SERMET
}

\begin{abstract}
Employees and employers should both be aware of the regulations governing employment in order to control and minimize industrial and individual disputes and conflicts. This study highlights the necessity of labour law awareness from the side of employees. The purpose of this paper is to determine and compare labour law awareness of employeesworking in Germany and Turkey. Data have been collected via questionnaire method from 345 employees in Turkey and 194 employees in Germany with a total number of 539. The data obtained from the respondents of the two countries have been analyzed and compared both in general and in accordance to mediating variables such as genders, tenure and membership of a union. As a result, there are considerable differences as well as similarities in awareness related to several aspects of labour law between the respondents of the two countries. The results indicate that respondents from both countries are highly aware of most of the regulations related to individual aspects investigated.However, they generally seem to have less knowledge about collective regulations according to their own evaluations.

Keywords:Labour law, labour law awareness, conflict, human resource management, comparative studies of countries.
\end{abstract}

\footnotetext{
* Correspondent Author: Assoc. Prof. Dr. Fulya Aydınlı Kulak, E-Mail: fulyaa@istanbul.edu.tr
} 


\title{
ÇALIŞANLARIN IŞ HUKUKU KONUSUNDAKI FARKINDALIKLARI: ALMANYA VE TÜRKIYE'DEN BIR KARŞILAŞTIRMA
}

\begin{abstract}
ÖZET
Işverenlerin ve çalışanların, istihdamı düzenleyen yasalar konusunda bilgi sahibi olmaları, toplu ve bireysel iş uyuşmazlıklarını ve çatışmaları kontrol altına almak ve en aza indirmek açısından gereklidir. Bu çalışmada; iş hukuku konusundaki farkındalığın önemi, çalışanlar açısından ele alınmaktadır. Çalışmanın amacı, Almanya ve Türkiye'deki yanıtlayıcı çalışanların iş hukuku konusundaki bilinç düzeylerini belirlemek ve karşılaştırmaktır. Veriler, Türkiye'den 345 ve Almanya'dan 194 olmak üzere toplam 539 çalışandan anket yöntemiyle toplanmıştır. Elde edilen veriler hem genel olarak analiz edilmiş ve karşılaştırılmış hem de cinsiyet, kıdem ve sendika üyeliği gibi değişkenler açısından gruplandırılarak karşılaştırılmıştır. Sonuç olarak, iki ülkedeki katılımcıların iş hukukunun çeşitli konularındaki farkındalık düzeylerinde benzerlikler olduğu kadar önemli farklılıkların da bulunduğu görülmektedir. Buna göre iki ülkeden katılımcılar da bireysel hususlara ilişkin incelenen düzenlemeler hakkında yüksek düzeyde bilinçli olduklarını belirtmişlerdir. Diğer yandan, katılımcılar toplu iş ilişkileri konusundaki bilgilerinin ise genel olarak nispeten az olduğunu değerlendirmektedirler.
\end{abstract}

Anahtar kelimeler:iş hukuku, iş hukuku farkındalığı, çatışma, insan kaynakları yönetimi, ülkeler arası karşılaştırmalı çalışmalar. 


\section{Introduction}

One of the objectives of human resource management (HRM) is to increase the productivity of the organization and hence contribute to the competitiveness by effective management of the employees, in such a way that this would be beneficial to the employees, the firms and the environment in which the organization takes place.HRM tries to accomplish this objective through its functions and their related activities. The effectiveness of these functions and their activities can be monitored through specific indicators such as labour turnover and absenteeism rates, customer complaints, performance ratings, accident rates and the rate of disputes whether individual or collective (Sadullah, 2013: 3).Thus all types of disputes between management and employees can prevent HRM from accomplishing its goal of improving productivity because of their inherent counterproductive nature.

We believe it is the responsibility of HRM to create and maintain an organizational climate which will enhance the employee-management relations that will effectively reduce the occurrence rate of these disputes. HRM, in other words, should conduct its functions and activities within the legal framework in a fair and affirmative way. In this context employees who have high awareness of their rights will contribute to the forming of the appropriate climate which will lower the dispute frequencies. Meager et al. (2002) and Casebourne et al.(2006) also state that being aware of employment rights may protect employees from having problems at work and may help them resolve these problems. Shackleton (2002) has stated that employees without having sound knowledge about their rights and obligations have claims that are not in line with the law. Therefore, the rise in claims as a result of this uncertainty increases level of disputes. So appropriate HRM practices will and should provide a work force that is aware of its rights and obligations so as to use them in a responsible way. On the other hand, if this awareness is not imparted by the management through HRM activities, employees aware of their rights might tend to create disputes if their rights are violated because of inept/unfitting HRM practices. As found by Cooke study (2008), one of the reasons for the rising level of disputes in China is the increasing number of employers violating regulations, either delibaretly or as a result of legal ignorance.

Essentially the term dispute is synonymous with the term conflict used in behavioral approaches and lack of knowledge/awareness is one of the important sources stated in conflict literature(See Luthans, 2002: 278; Bercovitch et al., 2009: 7; Robbins, 2001: 458). So our belief, also supported by Shackleton (2002), Meager et al. (2002), Casebourne et al. (2006)and Cooke (2008), that lack of knowledge and low awareness of labour law is a major factor in disputes between employers and employees led us to design this study.

Despite the adaptation of legislative systems of the developed countries in the new century and the high attention of the mass media about employment legislation, especially employees' awareness levels of their legal employment rights still need to be investigated. Examining current literature about labour law awareness, very limited research could be found. 
In our literature review we have met similar empirical studies conducted to evaluate employees' self-assessed awareness of the labour rights that are conducted in Great Britain(Meager et al., 2002: 14; Casebourne et al., 2006: 23; Blackburn and Hart, 2002: 20), India(Monga, 1983: 235), Malaysia (Othman et al., 2007: ix) and Armenia (OSCE, 2009: 3). The earliest research we could find about labour law awareness of employees was conducted in India between 1970 and 1976 (Monga, 1983: 235).On the other hand, most of the research we reached was carried out in Great Britain by the Department of Trade and Industry (DTI).

The benchmark surveys from DTI whose main aims were to assess employees' general awareness of their employment rights were first conducted in 2001 with 1,000 respondents(Meager et al., 2002: xi)and then in 2005 with 1,038 respondents(Casebourne et al., 2006: 6).According to the research findings, $70 \%$ of the respondents in 2001 assessed themselves, well / very well informed, about their employment rights. In the research, respondents were asked questions about parental leave, working time, minimum wage, antidiscrimination and unfair dismissal regulations and rights. Almost all the respondents of this survey (96\%) expressed themselves as aware of the National Minimum Wage rights. Moreover, anti-discrimination legislation is known by $91 \%$, unfair dismissal legislation is known by $90 \%$ and working time rule sare known by $72 \%$ of the respondents. However, only about $52 \%$ of them seem to be aware of parental leave rights(Meager et al., 2002: 22).

The second survey of DTI was again conducted in Great Britain in 2006. Similarly $66 \%$ of the respondents assessed themselves, well/very well informed, about labour law. Almost all the respondents seem to be aware of Race Discrimination Law (94\%), the National Minimum Wage (93\%), disability discrimination law (92\%), sex discrimination law (91\%) and unfair dismissal law (90\%).Another point, low awareness is found about regulations and rights related to parental leave( $27 \%)$, time off for dependents in an emergency (42\%) and additional maternity leave (49\%) (Casebourne et al.,2006: 2).

An earlier research was conducted in India with a sample of 277 employees in six industrial units located in State Haryana between 1970 and 1976 and the research findings were presented by Monga (1983: 235). In this research, the results of the investigation were: that only $19 \%$ of the respondents seemed to be aware of employment rights and regulations. Specifically, the Employees' State Insurance Act (87\%), the Employees' Provident Funds (and Family Pension Fund) Act (87\%) and the Factories Act (73\%) were more popular among workers, whereas these workers seemed to be unaware of the Minimum Wages Act (19\%), the Industrial Employment (Standing Orders) Act (22\%), the Industrial Dispute Act (23\%) and the Payment of Wages Act (25\%)(Monga, 198: 244-245).

Another DTI survey (Blackburn and Hart, 200: xiii) was conducted during July-August 2000 with a large-scale telephone survey of 1071 employers who are the owner-managers of the enterprises which were legally independent and employed between 1-50 employees. This time the research objective was to investigate employers' awareness and knowledge of individual employments rights (IERs) including maternity and parental leave, unfair dismissals, employment contracts, minimum wages, working time regulations and equal pay. 


\section{LABOUR LAW AWARENESS OF EMPLOYEES: A COMPARISON FROM GERMANY AND TURKEY: PROF. DR. ÖMER SADULLAH-ASSOC.PROF.DR. FULYA AYDINLI KULAK-MELTEM SERMET}

According to the self-assessments of the owner-managers, they are not confident about their knowledge of IERs. Only $20 \%$ of the participant employers (214 employers) could state that they found themselves confident/very confident regarding their general knowledge of IERs. Awareness about parental leave seems to be the lowest (49\%) whereas the employers seem to have very high levels of awareness about the National Minimum Wage regulations (99\%) and maternity leave regulations(96\%).

It is clearly seen that the existing literature regarding labour law awareness reveals few studies and by conducting this research we aim to contribute to the limited literature in this area and emphasize the necessity of labour law awareness in order for companies to control conflicts and decrease the number of disputes between employers and employees.

\section{Subject and objective of the research}

This research has been conducted to determine and compare labour law awareness of employees working in two different countries. The purpose of the study is to obtain information on labour law awareness of the participating employees in Germany and Turkey. More specific objectives are:

- to determine and compare the labour law awareness of participating employees in Germany and Turkey;

- to examine in which country the respondents know which of their rights and main regulations that are related to working life;

- to interpret the comparison of the labour law awareness of employees from both countries in relation to independent and dependent variables used in the research.

Obtaining information about labour law awereness levels of the participating employees provides us an idea about which individual and collective rights employees attach importance to or not. We can also interpret the country differences based on local regulations and contexts. Moreover, concerning issues employees do not attach great importance despite being crucial such as occupational safety and health, especially unions and other relevant parties should fulfil their functions in order to make employees aware of their rights. So the findings of this study also reveal the lack of employees' knowledge about legal issues influencing their working life. We also try to contribute to the interest and awareness of employees and employers about their rights and obligations.

\section{Research context and sample}

First of all, in our study the sample consists of the employees, who have an effective job contract and work in private sector in the two countries. The questionnaire has been given out only with those employees, who could answer "yes" to the following question: "Do you have a contract with a private company?". The respondents continued to fillout the questionnaire form. With the help of our questionnaire, the employees were asked if they know the main regulations related to signing and termination of contracts, working periods, annual leaves, labour unions and strikes.

The reason why Germany is chosen for comparison of labour law awareness is that Germany is a country with comprehensive and structural regulations and it has always been seen as one of the best countries for their detailed labour law regulations and their 
employees' rights (Körner, 2005: 805; Lingemann et al., 2008: 1;Conrad and Pieper, 1990: 109).

Germany's data has been collected from Stuttgart, Hannover and Erfurt. The three cities were chosen because they are at different geographical regions of the country and show different industrial structures. All German regions have strong industrial structures, but we took in consideration specifically those three cities because the information that was required was available from them. The questionnaire in Turkey has been conducted in Istanbul, Izmit and Bursa which are in the most industrialized region of Turkey. The cities in both countries are known for their developed industry and they were also chosen for their information availability. Because of the difficulties in collecting data from employees of two different countries, a convenience sampling method has been used. It means the data has been collected from the most accessible subjects (Marshall, 1996: 523). Questionnaires were completed between March and June 2012 in Turkey by 345 employees and in Germany by 194 employees with a total number of 539.

\section{Research model, variables and data collection method}

Independent variable of our research is the "country" variable as can be seen in Figure1. A questionnaire including six main dimensions and twentyitemshas been developed to identify labour law awareness of the individuals in the two countries. Each of the six dimensions that consist of several items is analyzed as dependent variables relevant for this study. Six dimensions used to measure labour law awareness of the employees are:

1. Labour law awareness in general and its necessity (two items),

Item 1: "Employees should have information about labour law."

Item 2: "I have general knowledge about the regulations of labour law."

2. Signing of a labour contract (four items),

Item 3: "I have signed my labour contract knowing that it complies with the governing acts."

Item 4: "I have knowledge about my employer's legal obligations concerning my safety and health at work."

Item 5: "I know that I should be insured on the first actual workday."

Item 6:"I know what my rights and obligations are during the trial period."

3. Terminating a labour contract (five items),

Item 7: "I know my rights and obligations when I terminate my labour contract."

Item 8: "I know what rights and obligations I will have when my employer terminates my labour contract."

Item 9: "I know the legal requirements for obtaining seniority compensation / severance pay."

Item 10:"When my contract is terminated by the employer, I know my seniority compensation /severance pay should be paid in full and immediately."

Item 11:"I know how long before I have to give prior notification or whether there is such obligation."

4. Working periods, overtime work and annual leaves (three items),

Item 12: "I know how many days of annual paid vacation I will deserve next year."

Item 13: "I have knowledge whether my weekly working hours comply with the legal designated working hours." 
LABOUR LAW AWARENESS OF EMPLOYEES: A COMPARISON FROM GERMANY AND TURKEY:

PROF. DR. ÖMER SADULLAH-ASSOC.PROF.DR. FULYA AYDINLI KULAK-MELTEM SERMET

Item 14: "If I stay for overtime, I have sufficient knowledge to evaluate the extra hours that I work is within the legally designated limits."

\section{Unions (threeitems),}

Item 15: "I know which unions are active in my branch of activity. "

Item 16: "I know how to become a union member."

Item 17: "I am afraid to become a union member because my contract might be terminated."

\section{Strikes (three items)}

Item 18: "As workers I know in which cases we can go on a strike or not according to concerning acts."

Item 19: "I know whether there is a ban on strikes about my work and / or workplace."

Item 20: "I know how the legal process is during the strike period."

We have not analyzed awareness about the bargaining aspect of labour law in our research, because in the bargaining process the employees do not directly participate in the negotiations and agreements. This process is conducted by a group of representatives chosen and authorized by the union to bargain in a collective approach (Dessler, 2010: 538). Therefore, we did not include items about bargaining process in our questionnaire.

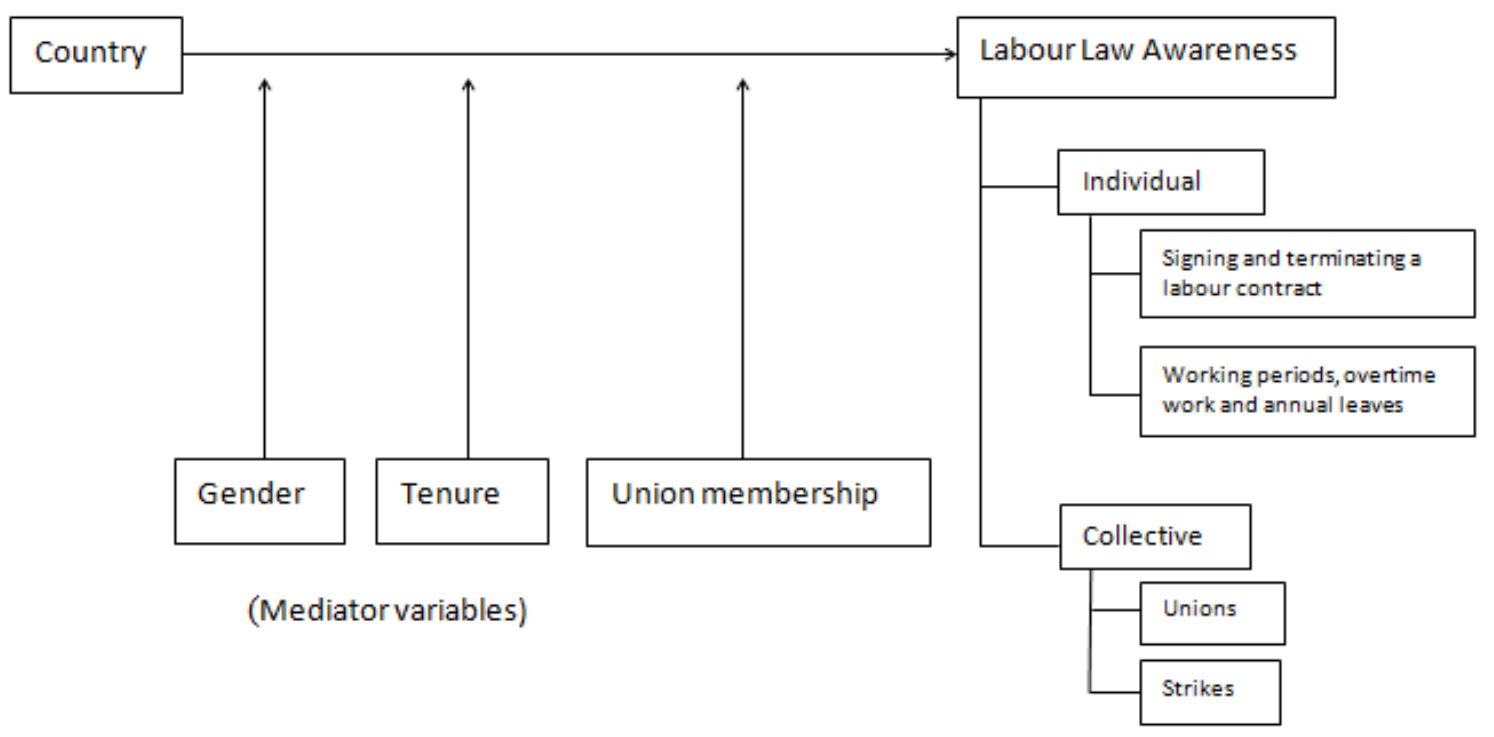

FIGURE 1. RESEARCH MODEL

Other than the above-mentioned dimensions of our study that include twenty variables measuring the labour law awareness of the employees, data related to the belowmentioned variables have beenobtained. Hence, as mentioned above the independent variable is the country variable and the mediator variables(Baron and Kenny, 1986: 1174) of the researchare as following (see Figure 1):

- Gender,

- Tenure,

-Membership of a union. 
A questionnaire has been developed in order to measure labour law awareness and collect compatible data in our subject. Our questionnaire includes dependent as well as independent variables. In the questionnaire Likert-type scale has been used. The level of agreement has been expressed using a five point scale like as (for the positive statements): $1=$ strongly disagree, $2=$ disagree, $3=$ =neither agree nor disagree, $4=$ =agree, $5=$ strongly agree. The dependent variables contain both positive and negative statements. In the negative statements we have used the scale categories vice versa. There are twenty items (mentioned above) used to evaluate labour law awareness of employees in terms of employees' labour law awareness in general, signing of a labour contract, terminating a labour contract, working periods, overtime work and annual leaves, unions and strikes. Moreover, additional questions have been asked respondents to indicate their age, gender, tenure, education, membership of a union and department.

At the beginning of the questionnaire we have asked respondents to indicate whether they work in a company at all or not (yes/no). This question intends to allow for a selection of this respondent/person relevant/suitable for our research.

For the sake of clarity and convenience, the language used in the questionnaire in Turkey was Turkish. For Germany, the original questionnaire form has been translated from Turkish to German by someone who can speak both languages as mother-tongue. Additionally, the German questionnaire has again been translated into Turkish in order to prove whether there is a difference between the original questionnaire and itself. In addition to re-translation, we applied the two survey forms (in Turkish and in German) at the same time to 10 employees who can speak and know both languages very well. Then, we compared the results and were sure that those employees had given the same answers for the statements.

The questionnaire form had been tested beforehand in both countries. In Turkey in our pre-test, the questionnaire has been filled out by 30 employees. In this pre-test, additional to Cronbach's alpha analysis we have had feedbacks from the respondents about the questionnaire and made some changes and additions. Similarly, in Germany the translated questionnaire has been pre-tested with 30 employees. Finally, the final version of our questionnaire form has been sent via e-mail and the forms have been filled out by face to face interviews in the two countries.

\section{Statistical analyses}

In analyzing the data firstly, means and standard deviations have been calculated for each item to see and compare labour law awareness levels in Germany and Turkey. Secondly, one-way Anova test has been used in order to investigate differences between the data of the employees in the two countries in general. Afterwards, the data have been separated into sub-groups according to several (mediating) variables that may have a potential to affect research results. These variables are:

- Genders (female and male),

- Union membership (member or not),

- Experience (less than 5 years, between 5-15 years and more than 15 years). 
After grouping the data, means and standard deviations have been calculated again for the itemsin each of the above-mentioned seven sub-groups. Finally, significance levels are calculated for each sub-group by using one-way Anova test.

\section{Reliability analysis}

In our study to determine the reliability of our questionnaire, we have calculated the coefficient of reliability (Cronbach's alpha value). In Turkey in our pre-test survey the reliability coefficient has been calculated as $\alpha=0,85$. In Germany the same pre-test has been made in accordance to translated questionnaire form and the Cronbach's alpha value, that has been calculated at the end of the reliability analysis of labour law awareness variables, is $\alpha=0,85$ as well. So we have found the scale to have good internal consistency (Cronbach, 1990).

\section{Findings}

In total 539 employees (194 from Germany and 345 from Turkey) who are working for private sector companies participated in the research. The demographics of the respondents can be seen in Table 1.Some of the respondents did not answer all of the questions related to the demographics.Only the percentages of those who answered the questions could be presented in the table. That's why the total number of samples is different for different groupings in Table 1.

The majority of the respondents in the two countries are experienced and middle-aged employees with university degrees and most of them do not have union membership. Distribution between manufacturing and services sectors of the employees in the two countries are similar. In both countries, respondents working in the manufacturing sector are mainly employed in automotive, food and chemistry fields whereas the ones working in services sector are usually employed in banking / finance, retails and educational fields.

TABLE 1: EMPLOYEE DEMOGRAPHICS

\begin{tabular}{|c|c|c|c|c|}
\hline \multirow[b]{3}{*}{ Gender $(n=539)$} & \multicolumn{2}{|c|}{ Germany } & \multicolumn{2}{|c|}{ Turkey } \\
\hline & $\%$ & $f$ & $\%$ & $f$ \\
\hline & & & & \\
\hline Female & 69 & 134 & 45 & 155 \\
\hline Male & 31 & 60 & 55 & 190 \\
\hline \multicolumn{5}{|c|}{ Education level $(\mathrm{n}=538)$} \\
\hline High school & 26 & 50 & 22 & 76 \\
\hline Technical college & 37 & 72 & 0 & 0 \\
\hline University & 28 & 54 & 63 & 217 \\
\hline Masters/PhD & 9 & 18 & 15 & 51 \\
\hline \multicolumn{5}{|l|}{ Age $(n=490)$} \\
\hline$<30$ & 20 & 38 & 40 & 121 \\
\hline $30-50$ & 63 & 119 & 56 & 168 \\
\hline$>50$ & 17 & 33 & 4 & 11 \\
\hline \multicolumn{5}{|l|}{ Experience $(n=529)$} \\
\hline$<5$ years & 16 & 30 & 34 & 116 \\
\hline $5-15$ years & 41 & 78 & 49 & 165 \\
\hline$>15$ years & 43 & 82 & 17 & 58 \\
\hline \multicolumn{5}{|c|}{ Union membership $(\mathrm{n}=531)$} \\
\hline Yes & 7 & 14 & 15 & 51 \\
\hline No & 93 & 180 & 85 & 286 \\
\hline
\end{tabular}


İş,Güç Endüstri İlişkileri ve İnsan Kaynakları Dergisi/Is,Guc The Journal of Industrial Relations and Human Resources, Temmuz/July 2015, Cilt/Vol: 17, Sayı/Num: 3, Sayfa/Page: 30-48

ISSN: 2148-9874, DOI: 10.4026/1303-2860.2015.0287.x

\begin{tabular}{lllll}
\hline Sector $(\mathrm{n}=506)$ & & & & \\
\hline Manufacturing & 55 & 106 & 46 & 144 \\
\hline Services & 45 & 86 & 54 & 170 \\
\hline Department $(\mathrm{n}=436)$ & & & & \\
\hline Sales/ Marketing & 28 & 52 & 30 & 74 \\
\hline HR & 12 & 22 & 17 & 42 \\
\hline Operation & 27 & 51 & 12 & 31 \\
\hline Other (Quality, Finance, Accounting, Planning, IT etc.) & 33 & 61 & 41 & 103 \\
\hline
\end{tabular}

In order to controldifferences in the research, that may derive from respondents' genders, years of experience and their union memberships, statistical analyses were first done in general and then by grouping the respondents according to their above-mentioned characteristics.

Examining Table 2, it is seen that employees in both countries strongly think that they should have information about labour law. However, the degree of necessity in Turkey $(M=4.75)$ is higher than that $(M=4.62)$ of Germany $(p=0.024)$. Examining Table 2 , the union members and less-experienced ( $<5$ years) respondents in the two countries showed that this difference in the degree of labour law awareness still exists even more clearly. So union membership and experience can be said to be the driving force between the difference in this regard in the two countries.

TABLE 2: LABOUR LAW AWARENESS AND ITS NECESSITY

\begin{tabular}{|c|c|c|c|c|c|}
\hline \multirow[b]{2}{*}{ Employees should have information about labour law. } & \multicolumn{2}{|c|}{ Germany } & \multicolumn{2}{|c|}{ Turkey } & \multirow[b]{2}{*}{ p } \\
\hline & $M$ & (SD) & $M$ & (SD) & \\
\hline General & 4.62 & $(0.807)$ & 4.75 & $(0.520)$ & $0.024^{*}$ \\
\hline Female & 4.60 & $(0.868)$ & 4.72 & $(0.600)$ & 0.172 \\
\hline Male & 4.67 & $(0.655)$ & 4.77 & $(0.444)$ & 0.152 \\
\hline Union members & 4.57 & $(0.514)$ & 4.84 & $(0.418)$ & $0.045^{\star}$ \\
\hline Without a union & 4.62 & $(0.827)$ & 4.72 & $(0.540)$ & 0.109 \\
\hline Experience: $<5$ years & 4.20 & $(1.400)$ & 4.73 & $(0.482)$ & $0.001^{*}$ \\
\hline $5-15$ years & 4.74 & (0.591) & 4.75 & $(0.578)$ & 0.921 \\
\hline$>15$ years & 4.63 & $(0.658)$ & 4.78 & $(0.421)$ & 0.151 \\
\hline \multicolumn{6}{|c|}{ I have general knowledge about the regulations of labour law. } \\
\hline General & 3.40 & $(1.317)$ & 3.51 & $(1.032)$ & 0.292 \\
\hline Female & 3.19 & $(1.346)$ & 3.54 & $(1.015)$ & $0.015^{\star}$ \\
\hline Male & 3.87 & $(1.127)$ & 3.49 & $(1.048)$ & $0.018^{*}$ \\
\hline Union members & 3.57 & $(1.089)$ & 3.82 & $(0.740)$ & 0.315 \\
\hline Without a union & 3.39 & $(1.334)$ & 3.45 & $(1.071)$ & 0.601 \\
\hline Experience: $<5$ years & 3.67 & $(1.269)$ & 3.28 & $(1.131)$ & 0.102 \\
\hline $5-15$ years & 3.10 & $(1.285)$ & 3.59 & $(0.981)$ & $0.001^{*}$ \\
\hline$>15$ years & 3.56 & $(1.353)$ & 3.71 & $(0.918)$ & 0.477 \\
\hline
\end{tabular}

NOTES: *Significant at the $\alpha=0.05$ level.

Employees in both countries state that they are moderately aware of the regulations in labour law in general (Germany: $M=3.40$; Turkey: $M=3.51$ ). However, general awareness of men in Germany and women who participate in Turkey is seen higher than their counterparts.

Significant differences can be observed on awareness about working hours and paid vacations between the employees in the two countries.As we can see in Table 3, awareness of employees in Germany is stronger than of the ones in Turkey. Since there is significant 
difference between non members in the two countries, strong awareness of German employees can be attributed to the efforts of the employers in advising their work force about their rights.

German employees are more aware of their rights concerning working hours, annual leaves and overtime than their Turkish counterparts. So we can say that they are more accurate about realization of contract conditions compared to Turkish employees. Excluding "annual leaves", employees are sometimes abused by employers in case of working hours in Turkey and the employees, concerned about their job security, may not be eager to defend their rights regarding working hours. Therefore, it is not surprising that Turkish employees do not attach great importance to that, if their actual working hours comply with the legal regulations or not.

TABLE 3: AWARENESS ABOUT WORKING HOURS AND PAID VACATIONS.

\begin{tabular}{|c|c|c|c|c|c|}
\hline \multirow{2}{*}{$\begin{array}{l}\text { I know how many days of annual paid vacation I will deserve next } \\
\text { year. }\end{array}$} & \multicolumn{2}{|c|}{ Germany } & \multicolumn{2}{|c|}{ Turkey } & \multirow[b]{2}{*}{$p$} \\
\hline & $M$ & (SD) & $\mathbf{M}$ & (SD) & \\
\hline General & 4.52 & $(0.934)$ & 4.31 & $(0.955)$ & $0.016^{*}$ \\
\hline Female & 4.46 & $(1.001)$ & 4.21 & $(1.017)$ & $0.032^{*}$ \\
\hline Male & 4.63 & $(0.758)$ & 4.39 & $(0.895)$ & 0.064 \\
\hline Union members & 4.57 & $(1.089)$ & 4.31 & $(0.927)$ & 0.378 \\
\hline Without a union & 4.51 & $(0.924)$ & 4.33 & $(0.953)$ & $0.039 *$ \\
\hline Experience: < 5 years & 4.20 & $(1.186)$ & 4.17 & $(0.935)$ & 0.892 \\
\hline $5-15$ years & 4.62 & $(0.841)$ & 4.35 & $(0.954)$ & $0.034^{*}$ \\
\hline$>15$ years & 4.51 & $(0.920)$ & 4.53 & $(0.977)$ & 0.891 \\
\hline \multicolumn{6}{|l|}{$\begin{array}{l}\text { I have knowledge whether my weekly working hours comply with } \\
\text { the legal designated working hours. }\end{array}$} \\
\hline General & 4.58 & $(0.760)$ & 3.75 & $(1.290)$ & $0.000^{*}$ \\
\hline Female & 4.58 & $(0.718)$ & 3.59 & $(1.385)$ & $0.000^{*}$ \\
\hline Male & 4.57 & $(0.851)$ & 3.88 & $(1.194)$ & $0.000^{*}$ \\
\hline Union members & 4.86 & $(0.363)$ & 3.82 & $(1.292)$ & $0.004^{*}$ \\
\hline Without a union & 4.56 & $(0.778)$ & 3.73 & $(1.298)$ & $0.000^{*}$ \\
\hline Experience: $<5$ years & 4.67 & $(0.606)$ & 3.66 & $(1.286)$ & $0.000^{*}$ \\
\hline 5- 15 years & 4.62 & $(0.743)$ & 3.68 & $(1.361)$ & $0.000^{*}$ \\
\hline$>15$ years & 4.51 & $(0.835)$ & 4.12 & $(1.077)$ & $0.017^{*}$ \\
\hline \multicolumn{6}{|l|}{$\begin{array}{l}\text { If I stay for overtime, I have sufficient knowledge to evaluate the } \\
\text { extra hours that I work is within the legally designated limits. }\end{array}$} \\
\hline General & 4.16 & $(1.261)$ & 3.84 & $(1.105)$ & $0.002^{*}$ \\
\hline Female & 4.12 & $(1.292)$ & 3.82 & $(1.114)$ & $0.035^{*}$ \\
\hline Male & 4.27 & $(1.191)$ & 3.86 & $(1.101)$ & $0.015^{*}$ \\
\hline Union members & 4.57 & $(1.089)$ & 3.84 & $(1.046)$ & $0.026^{*}$ \\
\hline Without a union & 4.13 & $(1.270)$ & 3.85 & $(1.110)$ & $0.010^{*}$ \\
\hline Experience: < 5 years & 4.07 & $(1.202)$ & 3.79 & $(0.974)$ & 0.194 \\
\hline $5-15$ years & 4.15 & $(1.239)$ & 3.79 & $(1.217)$ & $0.033^{*}$ \\
\hline$>15$ years & 4.17 & $(1.332)$ & 4.09 & $(0.978)$ & 0.682 \\
\hline
\end{tabular}

NOTES: *Significant at the $\alpha=0.05$ level.

It can be seen that the employees in both countries are well aware of their rights and obligations signing a labour contract. However, employees in Germany have a stronger awareness ( $M=4.21)$ about their employers' legal obligations concerning safety and health at work compared to the ones in Turkey ( $M=3.50)$ (See Table 4). Since considerable differences still occur when the respondents of the two countries are grouped according to their genders, union membership and experience, the overall difference of awareness in safety and health issues can be attributed to the country variable. We can assume that safety and health issues are not among the primary concerns of Turkish employees as opposed to job 
İş,Güç Endüstri İlişkileri ve İnsan Kaynakları Dergisi/Is,Guc The Journal of Industrial Relations and Human Resources, Temmuz/July 2015, Cilt/Vol: 17, Sayı/Num: 3, Sayfa/Page: 30-48

security and compensation issues. But among experienced employees ( $>15$ years) in both countries there is no difference relating to this issue. Experienced employees in both countries have high awareness about their employers's obligations concerning safety and health.

TABLE 4: SIGNING A LABOUR CONTRACT

\begin{tabular}{|c|c|c|c|c|c|}
\hline \multirow{2}{*}{$\begin{array}{l}\text { I have signed my labour contract knowing that it complies with } \\
\text { the governing acts. }\end{array}$} & \multicolumn{2}{|c|}{ Germany } & \multicolumn{2}{|c|}{ Turkey } & \multirow[b]{2}{*}{$\mathbf{P}$} \\
\hline & $M$ & (SD) & $M$ & (SD) & \\
\hline General & 3.99 & $(1.072)$ & 3.78 & $(1.087)$ & $0.033^{*}$ \\
\hline Female & 4.06 & $(1.081)$ & 3.80 & $(1.059)$ & $0.040^{*}$ \\
\hline Male & 3.83 & $(1.044)$ & 3.77 & $(1.112)$ & 0.690 \\
\hline Union members & 3.57 & $(1.453)$ & 4.08 & $(0.821)$ & 0.093 \\
\hline Without a union & 4.02 & $(1.035)$ & 3.73 & $(1.131)$ & $0.005^{\star}$ \\
\hline Experience: $<5$ years & 3.80 & $(0.925)$ & 3.76 & $(1.044)$ & 0.843 \\
\hline 5- 15 years & 3.82 & $(1.137)$ & 3.73 & $(1.123)$ & 0.548 \\
\hline$>15$ years & 4.20 & $(1.048)$ & 4.02 & $(1.100)$ & 0.334 \\
\hline \multicolumn{6}{|l|}{$\begin{array}{l}\text { I have knowledge about my employer's legal obligations } \\
\text { concerning my safety and health at work. }\end{array}$} \\
\hline General & 4.21 & $(1.047)$ & 3.50 & $(1.314)$ & $0.000^{*}$ \\
\hline Female & 4.21 & $(1.048)$ & 3.48 & $(1.321)$ & $0.000 *$ \\
\hline Male & 4.20 & (1.054) & 3.51 & $(1.312)$ & $0.000^{*}$ \\
\hline Union members & 4.71 & $(0.469)$ & 3.61 & $(1.401)$ & $0.005^{*}$ \\
\hline Without a union & 4.17 & $(1.070)$ & 3.46 & $(1.302)$ & $0.000^{*}$ \\
\hline Experience: < 5 years & 4.20 & $(0.847)$ & 3.37 & $(1.241)$ & $0.001^{*}$ \\
\hline $5-15$ years & 4.36 & $(1.006)$ & 3.38 & $(1.359)$ & $0.000^{*}$ \\
\hline$>15$ years & 4.07 & $(1.142)$ & 4.02 & $(1.221)$ & 0.782 \\
\hline \multicolumn{6}{|l|}{ I know that I should be insured on the first actual workday. } \\
\hline General & 4.65 & $(0.789)$ & 4.64 & $(0.762)$ & 0.865 \\
\hline Female & 4.63 & $(0.864)$ & 4.66 & $(0.714)$ & 0.685 \\
\hline Male & 4.70 & $(0.591)$ & 4.62 & $(0.800)$ & 0.452 \\
\hline Union members & 4.71 & $(0.469)$ & 4.75 & $(0.595)$ & 0.859 \\
\hline Without a union & 4.64 & $(0.809)$ & 4.63 & $(0.784)$ & 0.806 \\
\hline Experience: $<5$ years & 4.60 & $(1.102)$ & 4.48 & $(0.899)$ & 0.545 \\
\hline $5-15$ years & 4.54 & $(0.817)$ & 4.70 & $(0.655)$ & 0.093 \\
\hline$>15$ years & 4.76 & $(0.620)$ & 4.79 & $(0.695)$ & 0.741 \\
\hline \multicolumn{6}{|l|}{ I know what my rights and obligations are during the trial period. } \\
\hline General & 3.98 & $(1.263)$ & 3.80 & $(1.152)$ & 0.100 \\
\hline Female & 4.10 & $(1.228)$ & 3.99 & $(1.066)$ & 0.412 \\
\hline Male & 3.70 & $(1.306)$ & 3.65 & $(1.198)$ & 0.772 \\
\hline Union members & 3.14 & $(1.791)$ & 4.12 & $(0.952)$ & $0.008^{*}$ \\
\hline Without a union & 4.04 & $(1.195)$ & 3.74 & $(1.170)$ & $0.008^{*}$ \\
\hline Experience: $<5$ years & 4.53 & $(0.819)$ & 3.65 & $(0.819)$ & $0.000^{*}$ \\
\hline $5-15$ years & 4.03 & $(1.151)$ & 3.85 & $(1.111)$ & 0.269 \\
\hline$>15$ years & 3.68 & $(1.431)$ & 3.90 & $(1.266)$ & 0.363 \\
\hline
\end{tabular}

A note worthy finding here (Table 4) is that employees in both countries are fully aware of that they should be insured on the first actual workday. This item has the highest score in both Germany $(M=4.65)$ and Turkey $(M=4.64)$. The results do not change, concerning; neither employees' genders and experience, nor to that fact if they are members of unions or not.

Employees in both countries seem to know their rights and obligations when terminating a labour contract. Here, one thing to be considered is that employees in Germany are more aware of their rights and obligations when they terminate the contract $(p=0.030)$ (See Table 5). 


\section{LABOUR LAW AWARENESS OF EMPLOYEES: A COMPARISON FROM GERMANY AND TURKEY: PROF. DR. ÖMER SADULLAH-ASSOC.PROF.DR. FULYA AYDINLI KULAK-MELTEM SERMET}

There is also a considerable difference about the awareness of seniority compensation /severance pay in the two countries. However, this time it is clearly seen that employees in Turkey (regardless of their genders, experience and union memberships) know much about how to obtain seniority compensation. The 'seniority' compensation is a unique right in the Turkish Labour Act and its application is clearly defined. This compensation provides security to the employees whose contracts are terminated by the employers or upon retirement. Whereas in Germany the subject of compensation in case of termination is not as clearlydefined in the acts that govern employment and since there has been notable uncertainty (Goerke and Pannenberg, 2005: 1; Jahn, 2009: 2), this issue is perceived to be complex and difficult to understand by employers as well as employees in Germany (Pfarr etal., 2005: 5). Also the unemployment insurance is relatively new and perceived as insuffient in Turkey as compared to Germany (Şahin and Kızılırmak, 2007: 611). Therefore, it is not a surprising fact thatTurkish employees attach great importance to seniority compensation than the German employees.

TABLE 5: TERMINATING A LABOUR CONTRACT

\begin{tabular}{|c|c|c|c|c|c|}
\hline \multirow[t]{2}{*}{ I know my rights and obligations when I terminate my labour contract. } & \multicolumn{2}{|c|}{ Germany } & \multicolumn{2}{|c|}{ Turkey } & \multirow[b]{2}{*}{$p$} \\
\hline & $M$ & (SD) & $\mathbf{M}$ & (SD) & \\
\hline General & 4.13 & $(1.083)$ & 3.93 & $(1.023)$ & $0.030^{*}$ \\
\hline Female & 4.19 & $(1.072)$ & 3.88 & $(1.047)$ & $0.012^{*}$ \\
\hline Male & 4.00 & $(1.105)$ & 3.97 & $(1.005)$ & 0.863 \\
\hline Union members & 3.71 & $(1.541)$ & 4.02 & $(0.836)$ & 0.326 \\
\hline Without a union & 4.17 & $(1.038)$ & 3.91 & $(1.058)$ & $0.011^{*}$ \\
\hline Experience: < 5 years & 3.93 & $(1.202)$ & 3.91 & $(0.932)$ & 0.890 \\
\hline 5- 15 years & 3.92 & $(1.125)$ & 3.84 & $(1.100)$ & 0.570 \\
\hline$>15$ years & 4.41 & $(0.942)$ & 4.24 & $(0.961)$ & 0.290 \\
\hline \multicolumn{6}{|l|}{$\begin{array}{l}\text { I know what rights and obligations I will have when my employer terminates my } \\
\text { labour contract. }\end{array}$} \\
\hline General & 4.06 & $(1.177)$ & 3.98 & $(0.993)$ & 0.406 \\
\hline Female & 4.15 & $(1.141)$ & 3.99 & $(0.977)$ & 0.195 \\
\hline Male & 3.87 & $(1.241)$ & 3.98 & $(1.008)$ & 0.478 \\
\hline Union members & 3.57 & $(1.555)$ & 4.08 & $(0.821)$ & 0.103 \\
\hline Without a union & 4.10 & $(1.139)$ & 3.96 & $(1.020)$ & 0.185 \\
\hline Experience: $<5$ years & 4.07 & $(1.143)$ & 3.97 & $(0.918)$ & 0.641 \\
\hline 5- 15 years & 3.79 & $(1.252)$ & 3.90 & $(1.060)$ & 0.513 \\
\hline$>15$ years & 4.29 & $(1.094)$ & 4.22 & $(0.956)$ & 0.701 \\
\hline \multicolumn{6}{|c|}{$\begin{array}{l}\text { I know the legal requirements for obtaining seniority compensation / severance } \\
\text { pay. }\end{array}$} \\
\hline General & 3.49 & $(1.382)$ & 3.99 & $(1.092)$ & $0.000^{*}$ \\
\hline Female & 3.36 & $(1.406)$ & 4.05 & $(1.028)$ & $0.000^{*}$ \\
\hline Male & 3.80 & $(1.286)$ & 3.94 & $(1.142)$ & 0.416 \\
\hline Union members & 3.14 & $(1.703)$ & 4.06 & $(0.968)$ & $0.011^{*}$ \\
\hline Without a union & 3.52 & $(1.356)$ & 3.98 & $(1.108)$ & $0.000^{*}$ \\
\hline Experience: < 5 years & 3.73 & $(1.202)$ & 3.84 & $(1.154)$ & 0.641 \\
\hline 5- 15 years & 3.28 & $(1.404)$ & 4.03 & $(1.027)$ & $0.000^{*}$ \\
\hline$>15$ years & 3.56 & $(1.424)$ & 4.21 & $(1.072)$ & $0.004^{*}$ \\
\hline \multicolumn{6}{|l|}{$\begin{array}{l}\text { When my contract is terminated by the employer, I know my seniority } \\
\text { compensation /severance pay should be paid in full and immediately. }\end{array}$} \\
\hline General & 3.15 & $(1.398)$ & 4.40 & $(0.877)$ & $0.000^{*}$ \\
\hline Female & 3.06 & $(1.353)$ & 4.46 & $(0.839)$ & $0.000^{*}$ \\
\hline Male & 3.37 & $(1.484)$ & 4.35 & $(0.906)$ & $0.000^{*}$ \\
\hline Union members & 3.57 & $(1.555)$ & 4.47 & $(0.809)$ & $0.004^{*}$ \\
\hline Without a union & 3.12 & $(1.385)$ & 4.38 & $(0.893)$ & $0.000^{*}$ \\
\hline Experience: < 5 years & 3.13 & $(1.479)$ & 4.22 & $(0.949)$ & $0.000^{*}$ \\
\hline 5- 15 years & 3.05 & $(1.404)$ & 4.45 & $(0.852)$ & $0.000^{*}$ \\
\hline$>15$ years & 3.22 & $(1.397)$ & 4.60 & $(0.748)$ & $0.000^{*}$ \\
\hline
\end{tabular}


İş,Güç Endüstri İlişkileri ve İnsan Kaynakları Dergisi/Is,Guc The Journal of Industrial Relations and Human Resources, Temmuz/July 2015, Cilt/Vol: 17, Sayı/Num: 3, Sayfa/Page: 30-48

ISSN: 2148-9874, DOI: 10.4026/1303-2860.2015.0287.x

\begin{tabular}{|c|c|c|c|c|c|}
\hline General & 4.39 & $(0.982)$ & 4.09 & $(1.073)$ & $0.001^{*}$ \\
\hline Female & 4.42 & $(0.952)$ & 4.19 & $(1.043)$ & 0.052 \\
\hline Male & 4.33 & $(1.052)$ & 4.01 & $(1.093)$ & $0.045^{*}$ \\
\hline Union members & 4.14 & $(1.406)$ & 3.88 & $(1.227)$ & 0.498 \\
\hline Without a union & 4.41 & $(0.944)$ & 4.12 & $(1.047)$ & $0.003^{*}$ \\
\hline Experience: < 5 years & 4.47 & $(0.819)$ & 3.93 & $(1.117)$ & $0.015^{*}$ \\
\hline $5-15$ years & 4.26 & $(1.037)$ & 4.21 & $(1.015)$ & 0.720 \\
\hline$>15$ years & 4.49 & $(0.997)$ & 4.07 & $(1.153)$ & $0.023^{*}$ \\
\hline
\end{tabular}

NOTES: *Significant at the $\alpha=0.05$ level.

On the other hand, employees in Germany in general have a stronger awareness about notice periods(See Table 5). Although awareness about notice periods in Turkey seems to be weaker than notice period awareness of the respondents from Germany, it must be noted that this item has one of the highest scores of the respondents from Turkey. Therefore, respondents from both countries indicate that they have sufficient knowledge about notice periods.

Investigating awareness about unions in general in the two countries, significant differences are observed (See Table 6). First of all, employees in Germany are more aware of active unions in their branches of activities $(p=0.008)$. Comparing women in the two countries there are no significant differences on this issue.Employees in Germany also have more knowledge about how to become union members.

TABLE 6: UNION MEMBERSHIP

\begin{tabular}{|c|c|c|c|c|c|}
\hline \multirow[b]{2}{*}{ I know which unions are active in my branch of activity. } & \multicolumn{2}{|c|}{ Germany } & \multicolumn{2}{|c|}{ Turkey } & \multirow[b]{2}{*}{$p$} \\
\hline & $\mathrm{M}$ & (SD) & M & (SD) & \\
\hline General & 3.58 & $(1.409)$ & 3.26 & $(1.300)$ & $0.008^{*}$ \\
\hline Female & 3.34 & $(1.467)$ & 3.23 & $(1.297)$ & 0.471 \\
\hline Male & 4.10 & $(1.115)$ & 3.28 & $(1.306)$ & $0.000^{*}$ \\
\hline Union members & 4.00 & $(1.109)$ & 4.39 & $(0.777)$ & 0.134 \\
\hline Without a union & 3.54 & $(1.427)$ & 3.04 & $(1.270)$ & $0.000^{*}$ \\
\hline Experience: $<5$ years & 3.40 & $(1.653)$ & 3.03 & $(1.292)$ & 0.195 \\
\hline $5-15$ years & 3.59 & $(1.323)$ & 3.22 & $(1.283)$ & $0.038^{*}$ \\
\hline$>15$ years & 3.66 & $(1.416)$ & 3.78 & $(1.298)$ & 0.618 \\
\hline \multicolumn{6}{|l|}{ I know how to become a union member. } \\
\hline General & 3.59 & $(1.466)$ & 3.14 & $(1.408)$ & $0.001^{*}$ \\
\hline Female & 3.51 & $(1.545)$ & 3.09 & $(1.379)$ & $0.016^{*}$ \\
\hline Male & 3.77 & $(1.267)$ & 3.18 & $(1.434)$ & $0.005^{*}$ \\
\hline Union members & 4.43 & $(0.938)$ & 3.63 & $(1.469)$ & 0.058 \\
\hline Without a union & 3.52 & $(1.482)$ & 3.07 & $(1.373)$ & $0.001^{*}$ \\
\hline Experience: $<5$ years & 3.47 & $(1.697)$ & 3.08 & $(1.339)$ & 0.183 \\
\hline $5-15$ years & 3.62 & $(1.488)$ & 2.99 & $(1.392)$ & $0.002^{*}$ \\
\hline$>15$ years & 3.63 & $(1.383)$ & 3.71 & $(1.475)$ & 0.766 \\
\hline \multicolumn{6}{|c|}{$\begin{array}{l}\text { I am afraid to become a union member because my contract might be } \\
\text { terminated. }\end{array}$} \\
\hline General & 2.18 & $(1.296)$ & 2.60 & $(1.242)$ & $0.000^{*}$ \\
\hline Female & 2.25 & $(1.391)$ & 2.49 & $(1.159)$ & 0.116 \\
\hline Male & 2.00 & $(1.042)$ & 2.69 & $(1.303)$ & $0.000^{*}$ \\
\hline Union members & 1.43 & $(0.756)$ & 1.92 & $(1.214)$ & 0.155 \\
\hline Without a union & 2.23 & $(1.312)$ & 2.72 & $(1.216)$ & $0.000^{*}$ \\
\hline Experience: $<5$ years & 1.93 & $(1.143)$ & 2.78 & $(1.165)$ & $0.001^{*}$ \\
\hline $5-15$ years & 2.51 & $(1.287)$ & 2.67 & $(1.285)$ & 0.385 \\
\hline$>15$ years & 1.93 & $(1.322)$ & 2.09 & $(1.189)$ & 0.465 \\
\hline
\end{tabular}

NOTES: *Significant at the $\alpha=0.05$ level. 
The findings in Table 6 show that employees in both countries are not afraid to become union members. However, comparing employees in general, especially men as well as the non-union members and less experienced ones, we see that the scores in Germany are lower than the ones in Turkey in this regard.

Findings show that there is a considerable difference $(p=0.000,0.001,0.000)$ on the levels of awareness on strikes in the two countries. Specifically, general awareness on strikes is moderate $(M=3.18,3.05,3.14)$ in Turkey, whereas it is significantly lower $(M=2.74,2.65$, 2.69) in Germany.

TABLE 7: STRIKES

\begin{tabular}{|c|c|c|c|c|c|}
\hline \multirow{2}{*}{$\begin{array}{l}\text { As workers I know in which cases we can go on a strike or not } \\
\text { according to concerning acts. }\end{array}$} & \multicolumn{2}{|c|}{ Germany } & \multicolumn{2}{|c|}{ Turkey } & \multirow[b]{2}{*}{$p$} \\
\hline & M & (SD) & M & (SD) & \\
\hline General & 2.74 & $(1.257)$ & 3.18 & $(1.236)$ & $0.000^{*}$ \\
\hline Female & 2.75 & $(1.313)$ & 3.20 & $(1.197)$ & $0.002^{*}$ \\
\hline Male & 2.73 & $(1.133)$ & 3.17 & $(1.270)$ & $0.018^{*}$ \\
\hline Union members & 3.14 & $(1.512)$ & 3.82 & $(1.126)$ & 0.068 \\
\hline Without a union & 2.71 & $(1.235)$ & 3.08 & $(1.221)$ & $0.002^{*}$ \\
\hline Experience: $<5$ years & 3.07 & $(1.363)$ & 3.04 & $(1.175)$ & 0.925 \\
\hline $5-15$ years & 2.59 & $(1.178)$ & 3.15 & $(1.260)$ & $0.001^{*}$ \\
\hline$>15$ years & 2.73 & $(1.296)$ & 3.55 & $(1.245)$ & $0.000^{*}$ \\
\hline \multicolumn{6}{|l|}{$\begin{array}{l}\text { I know whether there is a ban on strikes about my work and / or } \\
\text { workplace. }\end{array}$} \\
\hline General & 2.65 & $(1.381)$ & 3.05 & $(1.357)$ & $0.001^{*}$ \\
\hline Female & 2.57 & (1.422) & 2.88 & (1.301) & 0.054 \\
\hline Male & 2.83 & $(1.278)$ & 3.19 & $(1.387)$ & 0.074 \\
\hline Union members & 2.71 & $(1.637)$ & 3.80 & $(1.327)$ & $0.012^{*}$ \\
\hline Without a union & 2.64 & $(1.364)$ & 2.92 & $(1.325)$ & $0.034^{*}$ \\
\hline Experience: $<5$ years & 2.73 & $(1.552)$ & 2.85 & $(1.314)$ & 0.668 \\
\hline 5- 15 years & 2.62 & $(1.154)$ & 2.95 & $(1.343)$ & 0.058 \\
\hline$>15$ years & 2.66 & $(1.549)$ & 3.78 & $(1.285)$ & $0.000^{*}$ \\
\hline \multicolumn{6}{|l|}{ I know how the legal process is during the strike period. } \\
\hline General & 2.69 & $(1.398)$ & 3.14 & $(1.263)$ & $0.000^{*}$ \\
\hline Female & 2.78 & $(1.418)$ & 3.01 & $(1.211)$ & 0.127 \\
\hline Male & 2.50 & $(1.347)$ & 3.24 & $(1.298)$ & $0.000^{*}$ \\
\hline Union members & 2.86 & $(1.512)$ & 3.71 & $(1.316)$ & $0.043^{*}$ \\
\hline Without a union & 2.68 & $(1.393)$ & 3.04 & $(1.228)$ & $0.003^{*}$ \\
\hline Experience: $<5$ years & 3.27 & $(1.507)$ & 2.89 & $(1.221)$ & 0.152 \\
\hline $5-15$ years & 2.56 & $(1.180)$ & 3.05 & (1.258) & $0.005^{*}$ \\
\hline$>15$ years & 2.54 & $(1.509)$ & 3.81 & (1.162) & $0.000^{*}$ \\
\hline
\end{tabular}

NOTES: *Significant at the $\alpha=0.05$ level.

\section{Discussion}

In this research, we have tried to measure employees' labour law awareness depending on their own evaluations. In addition, we focused on determining their awareness levels in several aspects of the labour law and by comparing the data of the respondents from Germany and Turkey, we have sought to determine in which country the employees are and are not aware of aspects of the labour law.

Examining the findings in detail, first of all, although respondents from Turkey think that they should have information about labour law, they feel more strongly about this compared to the respondents from Germany, their own evaluations of labour law awareness is statistically lower than the respondents from Germany in most of the dimensions investigated in this research. 
When we compare the data of the respondents from the two countries, we see that respondents from Germany seem to have more knowledge to evaluate whether their working hours, overtime periods and annual leave periods, comply with the legally designated periods/limits. This can be explained by German employers' efforts to provide information about the job by giving precise job descriptions that include working conditions and working hours deriving from the legal principle "duty of care" (Weber and Wrede, 1996: 47).

Again, German respondents have a better understanding of their employers and their own rights and obligations when their labour contract is terminated whether by themselves or by their employers. However, examining awareness about seniority compensation / severance pay, it is clearly seen that respondents from Turkey are more aware of this issue. In Germany it is customary but not obligatory, to offer severance pay to avoid a legal conflict when an employment agreement ends or the job relationship is no longer possible (Weber and Wrede, 1996: 134, Arbeitsgesetze KSchG §9 2009: 127, Goerke and Pannenberg, 2010: 7). Whereas in Turkey, if employment agreement is terminated by the employer, it is mandatory to pay severance compensation commensurate with the employee's seniority.

Research findings indicate that awareness of employees about collective regulations are low in both countries. Especially in Germany, the respondents state that they do not know much about strikes. The awareness about strikes of respondents from Turkey seems to be higher than the ones in Germany. The scores of the statements about strikes are the lowest of all the statements. Employees' low awareness about strikes in both countries can be explained by the fact that strike decision can only be made by the trade union representing employees according to related laws (6356 no. Trade Unions and Collective Labour Agreement Act -formerly 2822 no. Collective Labour Agreement, Strike and Lock-Out Act- in Turkey and $§ 9$ paragraf (3) of the Basic Law in Germany).

In both countries employees know that they should be insured on the first actual workday. The other issues that employees are fully aware of, in both countries can be stated as annual leaves and notice periods.

In both countries most of the respondents are not union members and they state in general that they are not afraid to become union members. As can be expected, the scores of union members in both countries in this regard are less than the overall scores.

Another finding which we consider noteworthy is that in Turkey occupational safety and health issues are not significantly considered as a serious problem by the respondents. Employees are not well aware of their employers' legal obligations in this regard. It means that they may work even if their employers do not fully provide safe working conditions. Another point, awareness of employees about employers' obligations in Germany gets sharply stronger when we focus on union members, whereas in Turkey even union members can not state that they know their employers' obligations related to safety and health.

The research conducted inevitably has some limitations. Firstly, we intended to control potential differences that may derive from respondents' genders, experience and union memberships. We conducted the research with employees working for private sector 
companies in cities with similar characteristics in the two countries. Therefore, it is not possible to generalize research results to all employees working in Germany and Turkey.

Secondly, in this research aiming at comparing labour law awareness of employees working in the two countries, we have not tested employees' knowledge about labour law regulations. Instead, we asked them their own opinions related to how much they know about labour law. Therefore, the awareness based on their self-evaluations has been compared.

Finally, as we have mentioned before, we used convenience sampling method in both countries which resulted in reaching only white collar employees. In some other research, collecting data of blue-collar employees, regarding this, would also be beneficial.

\section{Conclusion and Recommendations}

In this paper, we have tried to emphasize that not only employers but employees should also be aware of the regulations that manage and influence employment. High awareness of labour law in both parties may prevent potential disputes which serve/act as an obstacle to ensure high productivity. As Ferrell, Hirt and Ferrell (2011: 36) also state many problems and conflicts in business can be avoided if owners, managers and employees know more about business law and legal system.

As an overview, we can say that in both countries respondents seem to be highly aware of labour law regulations in general. This finding may be because the respondents of our research are white collar employees. Examining blue collar employees in this regard, may provide us different results. Also, we strongly recommend that a similar study should be conducted measuring employees' and employers' awareness of safety and health regulations. Even though a very recent Act (6331 no. Occupational Safety and Health Act) has been in effect since January 2013 in Turkey, this area needs special attention because of the recent accidents that claimed many lives especially in mining sector.

Even though this research is conducted on a limited number of employees, we aim to contribute to the interest and awareness of the relevant parties by focusing on employees awareness levels about main regulations of labour law. Here, one last thing to be considered is that we could find only limited similar research measuring labour law awareness of employees and employers in the literature. So we encourage future research to examine labour law awareness of especially blue collar employees due to that they might be more open to abuse/exploitation from employers because of their significantly lower education levels as compared to white collar employees. We consider this as an important factor in the case of Turkish blue collar employees. 


\section{References}

Arbeitsgesetze (2009). Kündigungsschutzgesetz (protection against dismissal act). Arbeitsgesetze: Bundeselterngeld- und ElternzeitG, Arbietnehmer-EntsendeG, KündigungsschutzG und andere Gesetze (75. Auflage), 124-135,Beck-Texte im dtv, München.

Baron, R.M.\& Kenny, D.A. (1986). The moderator-mediator variable distinction in social psychological research: conceptual, strategic, and statistical considerations, Journal of Personality and Social Psychology, 51(6), 1173-1182.

Bercovitch, J., Kremenyuk, V.,\& Zartman, I. W. (2009). Introduction: The Nature of Conflict and Conflict Resolution, in Bercovitch, J., Kremenyuk, V. and Zartman, I. W. (Eds.), The SAGE Handbook of Conflict Resolution,1-11,Sage Publications, London.

Blackburn, R.,\& Hart, M. (2002).Small firms' awareness and knowledge of individual employment rights,Employment Relations Research Series No.14.Department of Trade and Industry,Surrey.

Casebourne, J., Regan, J., Neathey, F.,\& Tuohy, S. (2006).Employment Rights at Work: Survey of Employees 2005,Employment Relations Research Series No.51, Department of Trade and Industry, London.

Conrad, P.,\&Pieper, R. (1990). Human resource management in the federal republic of Germany, in Pieper, R. (Ed.), Human Resource Management: An International Comparison,109-139, Walter de Gruyter, Berlin.

Cooke, F.L. (2008). The changing dynamics of employment relations in China: An evaluation of the rising level of labour disputes,Journal of Industrial Relations,50(1), 111-138. York.

Cronbach, L.J. (1990).Essentials of Psychological Testing,HarperCollins Publishers,New

Dessler, G. (2010).Human Resource Management (12.ed.).Prentice-Hall,New Jersey.

Ferrell,O.C.,Hirt, G.A.,\& Ferrell, L. (2011).Business: A Changing World(8. ed.),McGrawHill/Irwin.

Goerke, L., \& Pannenberg, M. (2010).Trade union membership and dismissals, Working Paper,3196,CESifo (Center of Economic Studies \& Institute for Economic Research), Munich.

Goerke, L.,\& Pannenberg, M. (2005). Severance pay and the shadow of the law: evidence for West Germany.Working Paper,1619, CESifo (Center of Economic Studies \& Institute for Economic Research), Munich.

Jahn, E.J. (2009). Do firms obey the law when they fire workers? Social criteria and severance payments in Germany, International Journal of Manpower, 30(7), 672-691.

Körner, M. (2005). German labour law in transition,German Law Journal, 6(4), 805-815.

Lingemann, S.,Steinau-Steinrück, R. \&Mengel, A. (2008).Employment \&Labour Law in Germany, Verlag C.H.Beck,Athens.

Luthans, F. (2002).Organizational Behavior(9. ed.),McGraw-Hill/Irwin,New York. 
LABOUR LAW AWARENESS OF EMPLOYEES: A COMPARISON FROM GERMANY AND TURKEY: PROF. DR. ÖMER SADULLAH-ASSOC.PROF.DR. FULYA AYDINLI KULAK-MELTEM SERMET

Marshall, M.N. (1996). Sampling for qualitative research,Family Practice,13(6), 522525.

Meager, N., Tyers, C., Perryman, S., Rick, J. \& Willison, R. (2002).Awareness, knowledge and exercise of individual employment rights,Employment Relations Research Series,15, Department of Trade and Industry, London.

Monga, M.L. (1983).Industrial Relations and Labour Law in India: Their Implementation and Awareness, Deep \& Deep Publications, New Delhi.

OSCE (Organization for Security and Co-operation in Europe Office) (2009).Awareness on the Role of Labor Rights and Trade Unions among Armenian Youth,APR Group, Yerevan.

Othman, W.S.D.W., Singh, K., \& Augustine, E.C. (2007).Study on the Level of Awareness of Employment Rights at the Workplace among Female Workers in Sarawak, Institute of Research, Development and Commercialisation (IRDC) of Universiti Teknologi MARA,Selangar.

Pfarr, H.M.,Ullmann, K., Bradtke, M., Schneider, J., Kimmich, M.,\& Bothfeld, S.(2005).Der Kündigungsschutz zwischen Wahrnehmung und Wirklichkeit. Betriebliche Erfahrungen mit der Beendigung von Arbeitsverhältnissen, Rainer Hampp Verlag,München.

Robbins, S. P. (2001).Organisation der Unternehmung(9. ed.),Pearson,München.

Sadullah, Ö. (2013). İnsan kaynakları yönetimine giriş (Introduction to human resource management), in Sadullah, Ö. (Ed.), Insan Kaynakları Yönetimi (Human Resource Management)(6. ed.), 1-46,Beta, ístanbul.

Shackleton, J.R. (2002).Employment Tribunals: Their Growth and the Case for Radical Reform, The Institute of Economic Affairs, London.

Şahin, H. \& Kızılırmak, A.B. (2007). Determinants of duration of unemployment insurance benefits in Turkey,Applied Economics Letters, 14(8), 611-615.

Weber, U. \& Wrede, B. (1996).German Labour Law: An Investor's Guide to German Labour Law, PfA Praktikerforum für Arbeits- und Wirtschaftsrecht GmbH,Köln. 